\title{
Standart Assesment of LSP-P1 For Students Dress Making in SMK Negeri 5 Malang
}

\author{
$1^{\text {st }}$ Sri Sulistyorini \\ Vocational Education \\ Universitas Negeri Malang \\ Malang, Indonesia \\ sulistyorinisri@gmail.com
}

\author{
$2^{\text {nd }}$ Purnomo \\ Department of Mechanical Engineering \\ Engineering Faculty, Universitas Negeri \\ Malang \\ Malang, Indonesia \\ purnomo@um.ac.id
}

\author{
$3^{\text {rd }}$ Agus Hery Supadmi Irianti \\ Department of Industrial Technology \\ Universitas Negeri Malang \\ Malang, Indonesia \\ agushery ft@um.ac.id \\ agushery um52@yahoo.co.id
}

\begin{abstract}
SMK graduates are ready-to-use workers at the intermediate level, a person's ability must be proven in completing work or task according to established performance standards. Package Expertise Dressing S MK Negeri 5 Malang, conducting competency tests through LSP-P1 SMK 5, to answer the needs of workers in the field of clothing according to the level of work on SKKNI. This research uses the qualitative method with case study approach. Interviews and observations obtained conclusion The role of educators on skills test in the field of dress Fashion is very dominant, while the awareness of learners in these activities still need guidance
\end{abstract}

Keywords-Assessment of competence; LSP P-1; SMK

\section{INTRODUCTION}

SMK as an educational institution that prepares graduates ready to work, got a big challenge with the existence of globalization, which is marked by the entry of foreign workers to Indonesia. The twenty-first century, vocational graduates should be able to form a person's competence to work. SMK graduates are ready-made workers at the middle level. A person's ability to work is seen from his ability to demonstrate his competence. The characteristics of a person mastering competence, mentioned in Decree of Minister of Manpower and Transmigration no. Kep. 90 / Men / V / 2010 as the ability of a person who can be observed includes the knowledge, skills and work attitude in completing a job or task in accordance with established performance standards. A graduate of SMK is also required to be able to be professional. Pakpahan and Narsoyo in Muryawanbroto (2012: 54) argues SMK graduates who are culturally professional characteristics as follows, (1) featuring good discipline habits; (2) unattended by others always try to work in a fast, precise and efficient way; (3) on their own endeavors always strives to maintain and develop their expertise; (4) have a sense of pride and love for his work and profession; (5) not misusing its expertise to the detriment of others; (6) respect and respect peers; and (7) has a value system in accordance with the profession [7]. Vocational education and training are developed by SMK based on real physical observable tasks to ensure that vocational students are competent in their areas of expertise. Students of SMK have competent value if able to show the real Achievement of student behavior, then the student must have a skill or a useful accomplishment he should know, what attitude should be held, how to do the students understand must work productively, and loyal to his work. This is reinforced by Permendikbud No. 20 the year 2016 on the Competency Standards of Basic and Secondary Education Graduates, Chapter II, that every graduate of elementary and secondary education units has competencies in three dimensions of attitude, knowledge, and skills. Skills learning in SMK should be able to answer the needs of skilled workers in a particular field of work. Therefore, the structure of the SMK curriculum will be very effective if prepared in line with the needs of existing work ladder SKKNI.

Student competence should also be tested for achievement by teachers, schools or government. Permendikbud No. 23 of 2016 on Education Assessment Standards provides that skills assessment is conducted to measure students' ability to apply knowledge when performing certain tasks. The Vocational Competency Test Assessment involves not only internal examiners who are expert or productive teachers, but involving external testers from industries, LSPs or academics who have met the requirements of the examiners (Sintawati, 2010: 1034) [12].

Presidential Instruction No. 9/2012 on Revitalization of Vocational High School in the Framework of Improving the Quality and Competitiveness of Human Resources of Indonesia, is interpreted as a major milestone in improving the quality of SMK graduates through several breakthroughs, including the involvement of the Professional Certification Board (BNSP) as institutions that have the authority to certify profession at SMK level. 
Since 2015, SMK in Indonesia has started to establish a professional certification agency licensed by BNSP. Terlicensinya Professional Certification Institute 1 (LSP-P1) in SMK, giving the authority of SMK to perform competency certification on their students. According to BNSP data base released in 2017, East Java is the province with the largest LSP-P1 with 262 LSPs, compared to other provinces.

Package Expertise Dressing in SMK Negeri 5 Malang, has conducted competency tests through LSP-P1 SMK 5 since 2015, as an effort to answer the needs of the workforce in the field of clothing that suits the level of work on SKKNI. This activity is included in the assessment activities at the end of the year of learning in SMK. The competency test by LSP P-1 that is relied upon to answer the flow of globalization on the scope of SMK, the implementation of course has its own path, therefore, this study aims to reveal the implementation of certification competency test package expertise fashion by LSP P-1 in SMK Negeri 5 Malang.

\section{THEORETICAL BASIS}

\section{A. Competency Assessment}

Regulation of Minister of Culture Education No.23 of 2016 on Education Assessment Standards Chapter III confirms that the purpose of the assessment is (1) by the educator to evaluate the learning process of seeing, learning progress, and improvement of learning outcomes continuously, (2) by the education unit for assessing the achievement of Graduate Competency Standards for all subjects; and (3) by governments to assess the achievement of Graduate Competency Standards for all subjects. Competence test in SMK is an assessment of student competency conducted by the government on vocational students. Mulyasa (2011) in Setiana et al (2015: 307) conveyed that theory and practice have a relationship that can not be separated from each other[11].

Evaluation of learning should be in accordance with the curriculum used, while the evaluation is conducted to monitor the process, progress and improvement of learning outcomes of learners. Evaluation of learning is an indicator to assess the achievement of objectives that have been determined and assess the process of implementation of teaching as a whole. The opinion of Rusman (2011) quoted by Hanum (2013: 95) says, "Evaluation is not just a spontaneous and incidental activity, but an activity to assess something in a planned, systematic, and purposefuldirection based on clear goals. " [10]

Based on the Implementation Guidance of Expertise Competency Test 2016-2017, SMK in Indonesia is given the flexibility to choose the implementation of competency test in 3 versions. The first version in the form of Vocational Competency Test (UKK) in cooperation with partner institutions, the second version in the form of LSP P-1, and the third Independent Vocational Competency Test (UKK). SMK which has established LSP P-1 to conduct competency test in XII class students through Vocational Competence Certification (PSKK) Implementation Test.

\section{B. Professional Certification Agency}

According to BNSP Regulation no. 2 / BNSP / III / 2014 concerning Guidelines for Establishment of Professional Certification Institution explained that Professional Certification Institution consists of 1st Party Certification Agency (LSP P-1) established by education and training institution, 2nd Party Certification Institute (LSP P-2) established by industry or agencies, and 3rd Party Certification Bodies (LSP P-3) are established by professional associations all under the license of the National Professional Certification Agency (BNSP). The existence of BNSP is intended to carry out the responsibilities given by the president with full authority for personnel certification and the task of performing certification of professional competence for the workforce. The irreversible impact of globalization forms a new paradigm in the preparation of manpower by taking into account BNSP principles that are, 1) the preparation of labor based on demand driven; and 2) the training process as a vehicle for the preparation of manpower is done by using a Competency Based Training (CBT) approach.

SMK in Indonesia in preparing students to be ready for work, encouraged to certify the field of expertise in students through LSP. Since 2014 until now many SMKs have LSP P-1 licensed, including SMK Negeri 5 Malang.

Licenses by BNSP are awarded to each scheme of specific skill packages according to SKKNI. The license is valid for 3 years, and as long as the license of LSP P-1 will be audited by BNSP once every year.

\section{Vocational High School in Indonesia}

Vocational High School (SMK) in Indonesia, is a formal education institution after junior high school (SMP), which conducts education and vocational training that prints its graduates ready to face the world of work. The support of the Indonesian government in the improvement of vocational education is evidenced by the issuance of Presidential Instruction No. 9 of 2016 on the revitalization of SMK in order to improve the quality and competitiveness of human resources in Indonesia.

This indicates the strength of the government's determination to immediately organize and improve the quality of Indonesian people through Vocational High School.

The learning in Vocational High School Indonesia is based on theory and practice to form specific, functional, skillful knowledge both physically and mentally as work preparation. Learning and training in SMK also involve institutions such as industry and business in the areas of expertise. Vocational High School students are considered competent if able to demonstrate the achievement of their behavior, then the student must have the skills or accomplishments he should know, what attitude should be held, how students understand to work productively, and loyal to the work according to the standards apply. 


\section{METHOD}

The research uses qualitative methods of case study approach, qualitative has the characteristics: to understand the phenomena experienced by subjects such as motivation, perception, action, etc., holistically, and by way of description in word form, into specific natural contexts and by utilizing natural methods by Cresswell (2014, p.247-249) [1] [2]. Furthermore, Yin (2011, p.8) says, "Qualitative research is driven by the desire to explain the event, through existing or emerging concepts". It is also said by Denzin and Lincoln (2000) in Ospina (2004, p.2) that "qualitative research is an interpretive and naturalistic approach: to interpret, the phenomenon in the meanings that people bring to them[8]. While Patton (2001) in Golafsani's study (2003, p.6) argues, "Qualitative research uses a naturalistic approach that seeks to understand phenomena incontext-specific settings, such as" real world setting [the] researcher does not attempt to manipulate the phenomenon of interest "[3].

The collection of qualitative research data is conceptual, conceptual, post priori and Ulfatin conceptual holistic (2015, p.167). Researchers collect data through documentation, behavioral observation, or interviews with participants. In this study, the researcher's presence as a full observer on all subjects to be explored and observed the process of its activities. Creswell (2014) states, "researchers are engaged in a sustained and continuous experience with participants". The steps were taken by researchers to be able to obtain the necessary data and meet the subject of research through the steps of orientation, exploration, and re-checking [1] [2]. Creswell $(2017,252)$ said the collection of research data, including: (1) documentation (2) visual material; (3) limiting research; (4) collect information through observation and interview; and (5) protocol design for recording / recording information, for example: title, instructions to be followed by participants, ice breaker questions and sub questions, thanks to interviewees, development of records to see whether the material shows the direct information or secondary note material originating from the second union[1] [2]. The focus of research to guide the search for information in the field, namely how the implementation of the assessment of the competence of Clothing in SMK Negeri 5 Malang through LSP-P1 BNSP test.

\section{DATA ANALYSIS}

Data analysis in this qualitative research is done during and after data collecting from the result of interview, observation and trace of the document. The analysis is done during the data collection process and after the data collection ends. Data analysis model in this case the researchers selected is Miles and Huberman model. Activities in data analysis such as data reduction, data display, and image / verification conclusions.

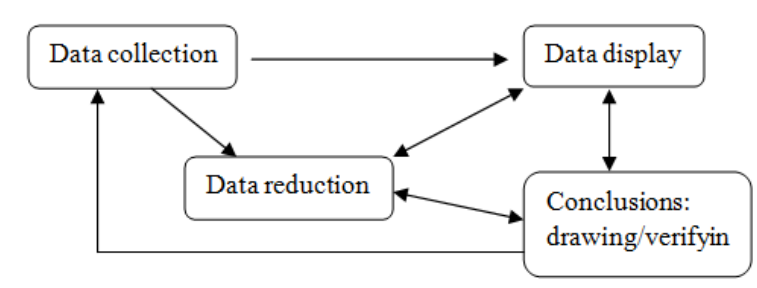

Fig I. Data analysis process model Miles and Huberman Source: Miles and Huberman (2014: 20)

Collected data will be tested its validity, that is by the test of credibility (internal validity), transferability test (external validity), dependability test (reliability), and confimability test [13]. The stages of this research consist of: Preparation includes: making research framework, choosing the location of research, taking care of permission, choosing informant, preparing research instrument in the form of question frame, maintaining ethics. Field stage includes: entering the field, data collection. Stages of data processing include: data reduction, data display, data analysis, conclusion.

\section{RESEARCH DAT A EXPLANATION}

To measure the achievement of a lesson, evaluation or assessment is conducted. Information from the assessment results will determine the status of the learners in the group. An evaluation conducted at SMK Negeri 5 Malang, including daily test, midterm exam and final exam of the semester.

In addition, the evaluation carried out by the Package Expertise Dressing SMK Negeri 5 Malang namely, PSKK test by BNSP. This information is similar to that expressed by the Deputy Head of School of Curriculum, Mr. Agus Supriyadi, S. $\mathrm{Pd}$, held in his office, the following.

"Evaluation conducted by schools in the form of UTS and UAS. I show again that we carry out is the evaluation done through prakerin program and LSP”. (W / Wkur 03/03032017)

Also delivered by Mr. Drs. Mahmudi, M.Pd acting as Head of SMK Negeri 5 Malang explaining about the evaluation of learning in this school, he said as follows.

"There is an evaluation of the middle of the semester we do, so that children do not forget, suddenly the end of the semester is too much material so that children focus more if we do evaluation mid semester. Then there is the final evaluation of the semester. There is another evaluation that for the 12th grade there is the name of UKK, this exam is for vocational, it is special practice. There is another evaluation of the National exam. Then in our school there is an evaluation of professional standards, from LSP (Professional Certification Institute). We have LSP level 1 so we have the authority to do the certification exam". (W / KS 03/03032017

Based on the result of the interview with the informant, the researcher got the findings that the evaluation or the assessment conducted in SMK Negeri 5 Malang, the midterm 
exam (UTS), the final exam of the semester (UAS), certification test or the implementation of vocational competency certification (PSKK) prakerin activities.

Implementation of vocational competence certification test (PSKK) by LSP 1 BNSP license at SMK Negeri 5 Malang in accordance with the mandate of Presidential Decree no. 9 of 2016 on the revitalization of SMK. PSKK Testing Program of Fashion Skill of SMK Negeri 5 Malang is followed by learners from Fashion Skill Program as many as 69 asesi, while asesor as many as three people from SMK Negeri 3 and SMK Negeri 7 Malang. The assessor acting as an appraiser in the PSKK test shall have an assessor certificate issued by BNSP, the lifetime of the assessor certificate for 3 years. In each activity an assessor has the authority to assess 20 assessments.

The test material is written test, practical test, and observation by the assessor. Competency Test Material (MUK) in the field of dressing arranged according to the level of work of vocational graduates ie as Junior Operator. From the interview with the principal in his office and field observation, the researcher finds that the PSKK Test by the Professional Certification Institute 1 (LSP P-1) in SMK Negeri 5 Malang is implemented so that the graduating student has professional standard and PSKK test result in 2017 this is converted by a vocational competency test (UKK).

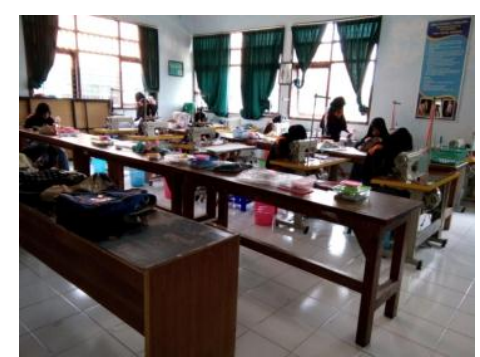

Fig I Implementation of PSKK Test in SMK Negeri 5 Malang. Document Owned by SMK Negeri 5 Malang

\section{DISCUSSION}

Evaluation of learning should be in accordance with the curriculum used, while the evaluation is conducted to monitor the process, progress and improvement of learning outcomes of learners. Evaluation of learning is an indicator to assess the achievement of objectives that have been determined and assess the process of implementation of teaching as a whole. The opinion of Rusman (2011) quoted by Hanum (2013: 95) says, "Evaluation is not just a spontaneous and incidental activity, but an activity to assess something in a planned, systematic, and purposeful direction based on clear goals. "

Evaluation or assessment that serves to measure the skill domain, is also listed in Permendikbud. 23 of 2016 that skills assessment is an activity undertaken to measure the ability of learners to apply knowledge in performing certain tasks performed by educators, educational units or government.

Assessment or evaluation in the form of competence test of student's skill generally done at every level when learning process takes place and at the end of education in school.
Skills competency test (UKK), whose implementation is under the control of the National Education Standards Board (BSNP), both the questioning, as sessment criteria, and testing standards (Sintawati, 2010: 1034).

The researcher's attention and need to be studied is whether the competency scheme in the cluster tested in PSKK test by LSP-P1 is in accordance with the curriculum subject structure of 2013 received by the learners during the learning. The role of educators to align the competencies composed in the LSP-P1 cluster scheme is an obligation and must be done immediately. The role of educational unit and educator becomes the key in the alignment of this competency test material will be efficient if the alignment of competency test materials based on BNSP standard competency cluster has done in class $\mathrm{X}$, so there is no sunset skill when the skill is not needed anymore in the exam or in the world of work, as well as for the creation of efficiency in teaching and learning activities.

\section{CONCLUSIONS}

This study concluded

- The role of educators in the implementation of skills test in the field of the dress is very dominant, while the awareness of learners in these activities still needs intensive guidance from educators.

- Implementation of PSKK test by LSP P-1 SMK 5 the year 2017, running well, orderly and smoothly.

- Socialization of PSKK test activity by LSP P-1 needs to be improved so that students and teachers prepare the test in sufficient time, and there is time to practice solving the PSKK test questions.

\section{REFERENCES}

[1] Cresswell J W 2014, Research Design, Qualitative Quantitative and Mixed Methods Approaches, Fourth Edition, SAGE Publiations.

[2] Creswell, J.W. 2017. Research Design Pendekatan Metode Kualitatif, Kuantitatif, dan Campuran (Terjemahan). Jogyakarta. Pustaka Pelajar

[3] Golafshani N 2003, Understanding Reliability and Validity in Qualitative Research, The Qualitative Report, 8(4), < http://nsuworks.nova.edu>

[4] Instruksi Presiden (Inpres) Nomor 9 tahun 2016 tentang Revitalisasi Sekolah Menegah Kejuruan Dalam Rangka Peningkatan Kualitas dan Daya Saing Sumber Daya Manusia Indonesia

[5] Keputusan Mentri Tenaga kerja dan Transmigrasi no. Kep. 90/ Men/ V/ 2010

[6] Miles, M. B. \& Huberman, A. Michel. 2014. Analisis dan Data Kualitatif ( BukuSumber Tentang Metode-metode Baru)( Terjemahan). Jakarta. Penerbit Universitas Indonesia

[7] Muryawanbroto. A, \& Ghufron.2012. Upaya Sekolah Menengah Kejuruan Dalam Menyiapkan Lulusannya Sebagai Tenaga Kerja Yang Professional . Jurnal Manajemen Pendidikan. (Online), 1 (1) , http://download.portalgaruda.org/article, diakses 12 Pebruari 2017 
[8] Ospina S, Wagner R F 2004, Qualitative Research. Encyclopedia of Leadership.Sage Publications, <http://ualr.edu>

[9] Pedoman Pelaksanaan Uji Kompetensi Keahlian tahun 2016-2017 Direktorat PSMK Dirjen Pendidikan Dasar dan Menengah

[10] Rusman, dkk. 2011. Pembelajaran berbasis teknologi informasi dan komunikasi,mengembangkan profesionalitas guru..Jakarta. PT. Raja Grafindo

[11] Setiana. Y.H, Siregar. S, Haryadi, 2015. Kontribusi Hasil Ujian Teori Terhadap Hasil Ujian Praktik Pada Uji Kompetensi Keahlian Siswa SMK. Journal of Mechanical Engineering Education, 2(2) ; hlm 307-311

[12] Sintawati, Esin. 2010. Pelaksanaan Uji Kompetensi Keahlian (UKK) Tata Busanadi SMK: Antara Kenyataan dan Harapan. APTEKINDO Seminar Internasional, Peran LPTK Dalam Pengembangan Pendidikan Vokasi di Indonesia ISSN 1907-2066
[13] Sugiyono. 2015. Metode Penelitian Pendidikan Pendekatan Kuantitatif, Kualitatif, dan $R \& D$. Bandung. Penerbit Alfabeta.

[14] Ulfatin N 2015, Metode Penelitian Kualitatif Di Bidang Pendidikan: Teori dan Aplikasinya, Media Nusa Creative, Malang- Indonesia

[15] Yin, R K 2011. Qualitative Research from Start to Finish, THE GUILFORD PRESS New York London 